\section{UDC: 35:159.955:316.6}

DOI: https://doi.org/10.32689/2617-

2224-2020-1(21)-57-70

Бобровський Олексій Ілліч, аспірант кафедри державного управління та місцевого самоврядування Дніпропетровського регіонального інституту державного управління Наиіональної академії державного управління при Президентові України; 49000, м. Дніпро, вул. Титова, 2, e-mail: bobelur@meta. иа, моб. т.: +38 (097) 5787475 .

ORCID: 0000-0001-7395-7477

Бобровский Алексей Ильич,

аспирант кафедры государственного управления и местного самоуправления Днепропетровского регионального института государственного управления Национальной академии государственного управления при Президенте Украинъ; 49000, г. Днепр, ул. Титова, 2, е-таil: bobelur@meta.ua; моб.т.: +38 (097) 578 7475.

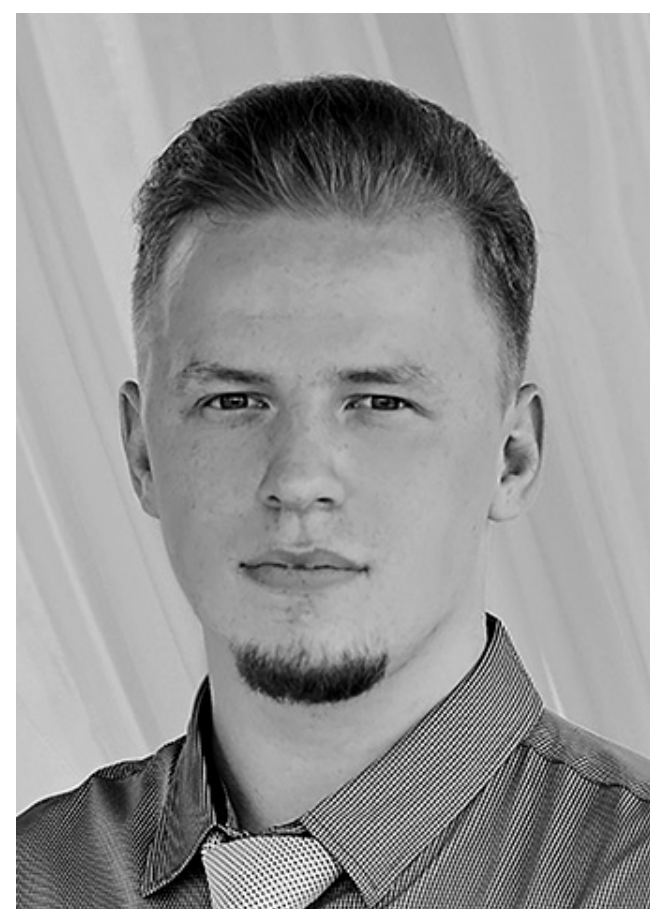

ORCID: 0000-0001-7395-7477

Bobrovskyi Oleksii Illich, graduate student of the Department of Public Administration and Local Government Dnipropetrousk Regional Institute of Public Administration of the National Academy of Public Administration, the President of Ukraine; 49000, Dnipro, Str. Titova, 2, e-mail: bobelur@ meta.ua; mob. tel.: +38 (097) 5787475.

\title{
АРХЕТИПИ МОДЕЛЕЙ УПРАВЛІННЯ I СИСТЕМНЕ МИСЛЕННЯ ЯК ЧИННИКИ РОЗВИТКУ ТРАДИЦІЙ ДЕМОКРАТИЧНОГО ДЕРЖАВОТВОРЕННЯ
}

Анотація. Обгрунтовано необхідність зміни підходів до побудови інноваційних шляхів підвищення ефективності публічної влади. Досліджено теоретичні засади формування і розвитку розумових здатностей людини і можливості їх застосування як соціально-психологічних чинників демократизації влади і підвищення ефективності публічного управління територіальних громад. 
Доведено доцільність включення соціально-психологічних чинників розвитку суспільства до складу чинників, які використовуються при побудові систем публічного управління. Сформовано уявлення про існування прямого зв’язку системного мислення й інтелекту людини з її архетипом, гіпотетично висловлюється думка щодо їх впливу на “несвідоме” особистості.

Розглянуто сутність понять “архетип”, “мислення”, “системне мислення”, “інтелект” й “інтелектуальні моделі" як інтелектуального підгрунтя опанування і розвитку кібернетичних системних архетипів управління як шляху інтелектуалізації і підвищення ефективності управління, починаючи з низових ланок суспільства. Доведено доцільність одночасного розгляду архетипічності людей, їх системного мислення й інтелектуальних моделей, що поглиблює їх взаємопов'язаність, взаємовплив і взаєморозвиток. Запропоновано модель пов'язаності, взаємодії і впливу ключових людських чинників розвитку на розвиток систем управління. Модель призначена для отримання уявлення про можливість застосування архетипного підходу і системного мислення при опануванні теоретичних і практичних знань майбутніми фахівцями науки державного управління. Вона ілюструє вплив акумульованих властивостей людини на створення і функціонування нового типу моделей управління процесами розвитку територіальних громад.

Показано, що запровадження архетипічного підходу, системного мислення і систем архетипів управління потребує створення базового аналітичного підгрунтя, яке має побудуватися на результатах дослідження кадрового складу й управлінських систем територіальних громад шляхом застосування аналітико-синтетичної моделі “Універсального епохального циклу”. Запропоновано доповнити концепцію побудови і розвитку систем управління територіальними громадами заходами із застосуванням архетипного підходу як нову можливість виявлення і задіяння інтелектуального потенціалу жителів до процесів розвитку територій і країни в цілому.

Ключові слова: соціально-психологічні властивості людини, архетип людини, системне мислення, інтелектуальні моделі, архетип системи управління, соціально-психологічні чинники підвищення ефективності управління, демократизація й інтелектуалізація процесів, управління розвитком.

\section{АРХЕТИПЫ МОДЕЛЕЙ УПРАВЛЕНИЯ И СИСТЕМНОЕ МЫШЛЕНИЕ КАК ФАКТОРЫ РАЗВИТИЯ ТРАДИЦИЙ ДЕМОКРАТИЧЕСКОГО ГОСУДАРСТВА}

Аннотация. Обоснована необходимость изменения подходов к построению инновационных путей повышения эффективности публичной власти. Исследованы теоретические основы формирования и развития умственных способностей человека и возможности их применения как социально-психологических факторов демократизации власти и повышения эффективности публичного управления территориальных общин.

Доказана целесообразность включения социально-психологических факторов развития общества в состав факторов, используемых при построении 
систем публичного управления. Сформировано представление о существовании прямой связи системного мышления и интеллекта человека с его архетипом, гипотетически высказана мысль об их влиянии на “бессознательное” личности.

Рассмотрена сущность понятий “архетип”, “мышление”, “системное мышление”, “интеллект” и “интеллектуальные модели” в качестве знаниево интеллектуального основания освоения и развития кибернетических системных архетипов управления, как пути интеллектуализации и повышения эффективности управления, начиная с низовых звеньев общества. Доказана целесообразность одновременного рассмотрения архетипичности людей, их системного мышления и интеллектуальных моделей, что углубляет их взаимосвязанность, взаимовлияние и взаиморазвитие. Предложенная модель связанности, взаимодействия и влияния ключевых человеческих факторов развития на развитие систем управления. Модель предназначена для получения представления о возможности применения архетипного подхода и системного мышления при овладении теоретическими и практическими знаниями будущими специалистами науки государственного управления. Она иллюстрирует влияние аккумулированных свойств человека на создание и функционирование нового типа моделей управления процессами развития территориальных общин.

Показано, что введение архетипического подхода, системного мышления и систем архетипов управления требует создания базового аналитического обоснования, которое должно строиться на результатах исследования кадрового состава и управленческих систем территориальных общин путем применения аналитико-синтетической модели "Универсального эпохального цикла”. Предложено дополнить концепцию построения и развития систем управления территориальными общинами мероприятиями с использованием архетипического подхода как новой возможности выявления и задействования интеллектуального потенциала жителей в процессы развития территорий и страны в целом.

Ключевые слова: социально-психологические свойства человека, архетип человека, системное мышление, интеллектуальные модели, архетип системы управления, социально-психологические факторы повышения эффективности управления, демократизация и интеллектуализация процессов, управление развитием.

\section{ARCHETYPES OF MANAGEMENT MODELS AND SYSTEMS THINKING AS FACTORS IN THE DEVELOPMENT OF THE TRADITIONS OF DEMOCRATIC STATE-BUILDING}

Abstract. The necessity of changing approaches to building innovative ways of improving the efficiency of public power is substantiated. The theoretical bases of formation and development of human mental abilities and possibilities of their application as socio-psychological factors of democratization of power and increase of efficiency of public management of territorial communities are investigated. 
The expediency of including social and psychological factors of social development into the factors used in the construction of public administration systems has been proved. The idea about the existence of a direct connection of systemic thinking and human intelligence with its archetype has been formed, and a hypothetical opinion has been expressed about their influence on the 'unconscious' personality.

The essence of the concepts 'archetype', 'thinking', 'system thinking', 'intelligence' and 'intellectual models' as the basis of intellectual development and development of cybernetic and system archetypes of management, as a way of intellectualization and improvement of management efficiency, starting from the grassroots levels of society is considered. The expediency of simultaneously considering the archetypical nature of people, their systemic thinking and intellectual models have been proved, which deepens their interconnectedness, mutual influence, and mutual development. The model of connectedness, interaction, and influence of key human factors of development are offered on the development of management systems. The model is intended to get an idea of the possibility of applying an archetypal approach and systemic thinking in mastering theoretical and practical knowledge by future specialists of public administration science. It illustrates the impact of accumulated human properties on the creation and operation of a new type of model for managing territorial community development processes.

It is shown that the introduction of the archetypal approach, systems thinking and systems of archetypes of management require the creation of a basic analytical basis. It should be built on the results of research on personnel composition and management systems of territorial communities through the use of analytical and synthetic models of the Universal Epochal Cycle. It is proposed to supplement the concept of building and development of territorial community management systems by applying an archetypal approach as a new opportunity to identify and engage the intellectual potential of residents in the processes of territorial development and the country as a whole.

Keywords: social and psychological properties of human, an archetype of human, systemic thinking, intellectual models, archetype of the management system, socio-psychological factors of increase of efficiency of management, democratization, and intellectualization of processes, and management of development.

Постановка проблеми. Організація ефективної системи публічного управління територіальних громад є однією з найважливіших проблем публічного державотворення в Україні. Рушійними силами суспільного і демократичного розвитку стають знання і колективна компетентність державних службовців, їх здатність до передбачень тенденцій і закономірностей розвитку, гнучкі, раціонально побудовані структурні схеми 
органів влади, їх внутрішні і зовнішні налагоджені, скеровані і збалансовані прямі й зворотні зв'язки при реалізації управлінських рішень.

Однак на сучасному етапі в публічному управлінні України ні організація управління, ні рівень компетенцій управлінських кадрів недостатньо забезпечують своєчасне і якісне вирішення актуальних проблем життєдіяльності українського соціуму. Особливої гостроти набули вони на територіальному рівні. При реформуванні місцевого самоврядування надані територіальним громадам нові права досі повністю не реалізовані. Територіальні громади не забезпечені ефективними організаційними моделями розробки і реалізації процесів управління, не мають достатньої кількості досвідчених, інноваційно мислячих керівників і державних службовців, які б повністю прийняли нові умови господарювання і почувалися господарями власного життя. В управлінні продовжують використовуватися традиційні підходи до побудови систем організацій управління і зв’язків між вищими органами влади, бізнесом та суспільством. Не змінився характер поведінки державних службовців. Їх повноваження і бачення власного майбутнього поки не відрізняється достатньою самостійністю.

Загрозливим стає загальний психологічний стан суспільства, адже поглиблюється недовіра до влади, ïi можливостей і здатностей створити новий клімат у суспільстві. Стає очевидним, що прогресивний суспільний рух потребує формування нових управлінських традицій, нового підходу до змістовно-функціонального й організаційного проектування систем управління і методичного супроводу владних дій.

Зважаючи на те, що діяльність людей є основою їх свідомого існування і розвитку, надзвичайно актуальним стає застосування соціально-психологічних чинників в удосконаленні систем державного й муніципального управління. Існування складних проблем в забезпеченні прогресивного соціального руху суспільства мотивує до пошуку нових шляхів покращення існуючого стану.

Аналіз останніх досліджень та публікацій. Соціальним призначенням держави та їі соціальним обов'язком стосовно своїх громадян є створення умов для їх розвитку, забезпечення потреб і участі в побудові демократичної платформи свого життя. Але в публічному управлінні територіальними громадами для вирішення цієї проблеми поки не існує ні дієвих програм, ні планів. При дослідженні теорії і практики управління особливе місце займає людина, як головний об'єкт і суб'єкт державної управлінської діяльності і суспільного розвитку. Тому кардинальне поліпшення ситуації в Україні неможливе без розробки нових сценаріїв розвитку демократичного суспільства, формування нових управлінських традицій і правил, широкого залучення мислячих та інтелектуально розвинутих громадян. На це спрямовуються теоретичні й практичні дослідження формування умов для підвищення творчої здатності глибинного психологічного розвитку архетипів людей i їх спільнот з метою активізації і задіяння їх у системах життєзабезпечення і розвитку людства. 
Питання процесів ментальних змін, які зачіпають соціальний статус людей у контексті політичних, культурних і соціальних вмістів, принципів регуляції здатності емоційної активності суб'єктів, глибинних чинників відтворення активності в процесах діяльності стали предметом досліджень багатьох зарубіжних учених: В. Ядова, А. Широзія, Д. Узнадзе, М. Одинцової та інших представників шкіл психології діяльності О. Леонтьєва і психологї настановлення Д. Узнадзе [1].

Українські вчені, представники української школи архетипіки академіка Е. Афоніна (А. Мартинов, О. Суший, О. Донченко, Т. Новаченко, О. Балакірєва, С. Благодєтєлева-Вовк, В. Друк, Т. Бельська, Н. Гавкалова та багато інших) $[1 ; 2 ; 3 ; 4 ; 5 ; 6$; 7], крім вищеперелічених напрямів досліджують архетипічні складники державного управління, архетипічності розвитку традицій суспільства, розвитку психологічної аналітики, участі несвідомого у вирішенні соціальних проблем; розробляють методологічні засади досліджень індивідуального й колективного несвідомого в соціальній та інших сферах життєдіяльності. Нова методологія і техніка психосоціального аналізу суспільства Е. Афоніна реалізується із застосуванням моделі "Універсального епохального циклу”.

Водночас окремі питання практичного використання архетипів людини в реформаторських процесах демократизації влади в суспільстві ще чекають свого вирішення. Одне із таких питань є застосування архетипічного підходу, тобто формування системного мислення й інтелекту- альних моделей людей при побудові системних архетипів публічного управління територіальними громадами.

Мета статті: з'ясувати невикористані можливості архетипічного підходу і системного мислення як факторів нівелювання застарілих традицій управління для підвищення ефективності діяльності управлінських кадрів; знайти нові шляхи взаємодії влади й активних членів суспільства за рахунок їх згрупування і порозуміння за допомогою розвитку їх архетипічних метанастанов, системного мислення і використання системних архетипів управління при формуванні органів управління, підготовці і підборі кадрів на державну службу.

Виклад основного матеріалу. Життя українського народу з початку третього тисячоліття супроводжується серйозними збуреннями: з'являються нові політичних сили, частішають економічні й соціальні негаразди, знецінюється роль історичних коренів, змінюються традиції, уподобання, людські цінності, зникає міжнаціональна повага, що розпорошує базові цінності й негативно впливає на свідомість населення. Сприйняття нових реалій створює глибокі зсуви під час формування особистісної і колективної свідомості людей і не надихає їх до активної діяльності в нових умовах. Хоча паростки позитивних настроїв вже пустили своє коріння, що доведено українськими вченими [8; 9; 10]. Це сприяє самореалізації і відтворенню енергії суспільних дій, збільшенню i розвитку традицій українського народу. 
Однак на сьогодні настрої, сподівання і прагнення населення не реалізовані. Це розуміє й українська влада, яка, як зазначають українські вчені, “вже не претендує на монополію насилля і заборони, а намагається функціонувати як техніка управління життям у формі порад і рекомендацій спеціалістів" [10, с. 11].

Очевидно, що без активної участі жителів країни в реалізації обраних державою цілей розвитку такий стан у суспільстві не здатні змінити ні обрана політика, ні науково обгрунтовані й ухвалені довгострокові плани розвитку. Для відтворення суспільної злагоди, взаємодії і гармонійної діяльності влади із суспільством необхідна серйозна зміна мислення соціуму й перебудова організації діяльності влади [11].

Зміна свідомості "метанойа" (трансцендентування) в християнській традиції наголошувалась як прозріння і проникнення в сутність високого Бога [12]. Згодом вона стала об’єктом дослідження багатьох учених. Із поняття “свідомість” людини була виділена та їі частка, яку людина не може розпізнати і виокремити. Така особливість людини i спільноти була названа архетипом. Вперше філософське тлумачення терміна “архетип” здійснив К. Юнг і його послідовники, а пізніше - Авіцена і багато інших дослідників, які аналізували індивідуальне і колективне несвідоме, породжуване у людей якимось дивним способом [13]. Тривалий час архетип розглядається як одна із характерних рис людини i спільноти, яку складно виділити і формально описати. Хоча вважається, що існують межі спілкування і діяльності людини, в яких iï архетип може проявлятись досить чітко, а саме: під час прояву професійних і соціальних якостей людини, при оцінюванні під час прийняття на певну посаду, при спілкуванні, у професійній діяльності тощо. Вважається, що архетип людини впливає на ii1 здатність і бажання до навчання, опанування нових компетенцій i формування у людини процесів мислення. При цьому розвивається і сам архетип. "Несвідоме" живиться за рахунок нових знань, навичок, нових зв'язків і збільшує силу впливу на менталітет людини. Під час групової діяльності чи навчанні підживлений індивідуальний архетип змінює групове “несвідоме” і менталітет. Однак "менталітет не дається людині з народження, а культивується як спосіб мислення, світосприйняття та характер емоційного життя" [10, с. 9]. Менталітет розглядається як історично зумовлена специфіка мислення, сукупність і форми організації особливостей соціальної та політичної психології людей, їх соціокультурного свідомого. Це наштовхує на думку, що досліджуючи “архетип” людини, одночасно слід розглядати і такі їі властивості, як спосіб мислення, системне мислення, інтелект і інтелектуальну модель.

3 метою кращого розуміння формування архетипних здатностей людини гіпотетично передбачимо, що наголошені якості людського розуму і діяльності безпосередньо пов'язані з архетипом, хоча поки не зовсім зрозуміло як само. Розглянемо ці якості більш детально.

Для характеристики особливостей мислення К. Юнг поділив людей 
на екстравертів та інтровертів. Серед складників загального мислення виділяють “швидкість, глибину мислення, широту мислення, гнучкість мислення, стратегічність, рефлексію (самосвідомість) і організованість" [13]. Характерною особливістю способу мислення визначається його здатність набувати нову якість в його вищому кумулятивному виразі - стані системного мислення, яке дозволяє виявляти зв’язки аналізованого явища не як множину об'єктів чи суспільних подій, а як закономірності і здійснювані в них системні зміни. I хоча ці зміни не завжди можуть бути описані якісними чи кількісними показниками, вони допомагають скласти уявлення про тенденції чи циклічний характер змін у суспільстві, окремих системах і ланках, які забезпечують його функціонування. Системне мислення пов'язане та ідентифікується 3 моделлю людської свідомості і підсвідомості (архетипом людини), на який можна впливати шляхом підсвідомого спрямування для більш глибокого розуміння таємниці створення людського свідомого і несвідомого та прогнозувати їх прояв у процесах соціальної еволюції і діяльності людини в соціумі. За наявності таких властивостей у людини можна передбачити, що вони здатні втілюватися в i архетип, розвиватись і проявлятись у спілкуванні з іншими людьми. Очевидно, що властивості доцільно розглядати як невід'ємні і пов’язані між собою особливості людини, які можуть утворюватися і розвиватися при набутті нею нових знань, компетентнісних навичок i досвіду. Розвиток мислення людини на певному етапі починає формувати так зване системне мислення. Воно являє собою “концептуальну рамку сукупності різних за останні 50 років знань і інтуїцій, призначених для більш легкого сприйняття цілісності явищ, що допомагає в досягненні змін” [12, с. 23] (переклад автора - О. Б.). До такого мислення в практичній діяльності приводить спостерігання прямих і зворотних зв'язків, бачення цілісності не як його статичного стану, а як низки закономірних змін, які підсилюють здатність явища до протидії небажаним впливам, створення його рівноваги і збалансованості. Загальне і професійне навчання, культура і набуття досвіду, системне мислення розвивають інтелектуальні здібності людини. Але архетип і інтелект людини це не одне й те саме. На відміну від архетипу інтелект людини створюється і піддається розвитку. За словами Альберта Енштейна, творіння інтелекту переживають шумну суєту поколінь і впродовж століть зігрівають світ теплом і світлом. На сьогодні наука, що досліджує інтелект дає понад 70 його визначень. Спільним у них можна виділити цілісність і системність ментального розумового досвіду, його здатність до діяльності і психологічні особливості людини. Розвиток інтелекту спрямовується на формування інтелектуальної моделі людини, яка відображає в їі свідомості певні положення, узагальнення, картини чи навіть образи, що впливають на 111 розуміння світу й обрання способів дій. Одним із важливих і потенційно цінних можливостей системного мислення вважається те, що його застосування дозволяє 
отримати уявлення стосовно того, що деякі прояви поведінки процесів структури того чи іншого явища виникають знову і знову. Такий прояв уявлення був названий типом структури, а утворення явищ архетипом системи у т. ч. "межі зростання”, “зміна проблеми”, “шаблон поведінки” та ін. [12, с. 109]. Цей тип архетипів порівнюється з історіями і ситуаціями, чи станом систем, які повторюються в різних умовах не один раз, а значно більше. Це явище відображається в різних напрямах знань (біології, економіці, управлінні, психології та ін.), що дає можливість об'єднувати значну кількість повторюваних ситуацій у значно меншу кількість архетипів, якими можна управляти.

Визнання існування архетипів людей і врахування можливостей опанування ними системного мислення та формування інтелектуальних моделей дає змогу розпізнавання поведінки складних систем й існування в них взаємовідносин, їх стійкої періодичності чи постійної повторюваності, які дістали назву “системні архетипи” і в першу чергу “архетипи систем управління”. Їх визначенню слід завдячити науці кібернетика, яка запропонувала шість типів системних архетипів управління.

Термін “архетип” в кібернетиці тлумачиться як високий ступінь абстракції системи, завдяки чому кожній системі надається певний статус, який характеризує рівень розвитку знань і вмінь управління [14]. Архетип систем управління відображає принципи і контури управління з використанням інформаційних потоків, що стає його візитною карткою. У складі запропонованих кібернети- кою архетипів систем управління загальний архетип, в якому реалізуються такі принципи, як: взаємодія систем управління із зовнішнім середовищем, принцип чорної скриньки, принцип зворотного зв’язку. 3 урахуванням загального архетипу була запропонована низка системних архетипів: архетип системи управління із розімкнутим контуром, архетип системи управління із замкнутим контуром, архетип адаптивної системи управління, архетип системи, в якому реалізуються алгоритми оптимального управління й архетип рефлексійного управління [15; 16].

Для виявлення, опису й аналізу архетипів систем управління зусилля повинні спрямовуватися на використання вищої форми концентрації знань і вмінь, які були б здатні реалізовувати алгоритми управління. Так, керування системним архетипом рефлексійного управління передбачає необхідність володіння сукупністю знань науки управління про керовані об'єкти, інтерпретацію знань публічного управління за функціями для перебудови цих знань у процесах функціонування i самоорганізації систем, моделі і алгоритми управління. Це дозволить вирішувати завдання з розпізнавання зовнішнього середовища і технологій підготовки відповідної реакції на впливи об'єктів управління, виділення причинно-наслідкових ланцюгів, тенденцій і закономірностей, ідентифікацію факторів, побудову аналітичних і статичних моделей і їх аналізу.

Для розпізнавання і використання архетипів систем управління, 
виокремлених наукою кібернетики, необхідно створити умови їх гармонізації з колективними архетипами управління (їх колективним несвідомим), оскільки це явище є неявним і майже некерованим. Мова може йти про інші здібності людей, які будуть імплементувати позитивні архетипні властивості управлінців в управлінську діяльність і реалізовувати їх в управлінні. В архетипному підході до застосування системних архетипів управління пропонується розглядати способи мислення, системне мислення, інтелект й інтелектуальні моделі, які можуть з певною умовністю вважатися ключем до інтуїції та підсвідомості. Логічна структура пов'язаності і взаємодії ключових людських чинників, їх включення в розвиток систем управління наведена на рисунку.

Модель призначена для отримання уявлення про можливість застосування архетипного підходу і системного мислення при опануванні теоретичних і практичних знань майбутніми фахівцями науки державного і муніципального управління. Вона ілюструє вплив акумульованих властивостей людини на створення і функціонування нового типу моделей управління процесами розвитку в територіальних громадах. Наведену модель пропонується використовувати в дослідженнях проблем підвищення ефективності управління на змістовно-функціональному, проектно-конструкторському, технологічному та експериментальному етапах модернізації органів публічної влади для забезпечення органів влади інтелектуально розвинутими працівниками.

Функціонування сукупності моделей типу системних архетипів управління і зв'язків між ними можуть створити базову основу формування нового психологічного клімату в управлінні суспільством за рахунок інноваційних технологій соціальної гармонізації, спільного бачення і взаємодії для досягнення цілей розвитку спільного життя. Доцільним є і застосування запропонованої нами моделі під час розробки стратегічних і поточних заходів розвитку країни та їі регіонів.

Слід зазначити, що в існуючих моделях систем управління, у складі методів їх побудови (лінійні, функціональні, лінійно-функціональні,

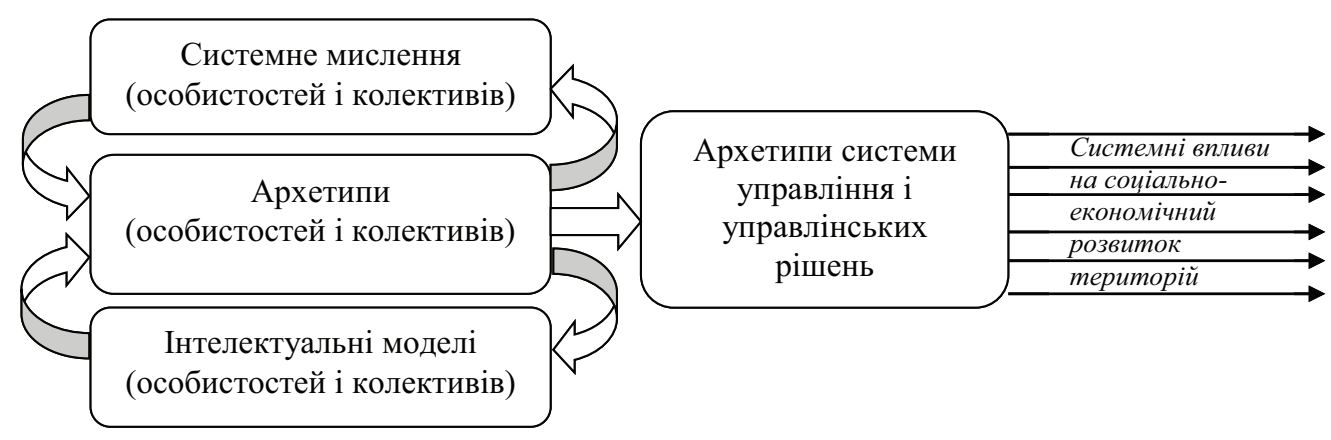

Рис. Модель пов'язаності, взаємодії і впливу ключових людських чинників на розвиток систем управління 
матричні, дивізіональні, штабні) і в підборі кадрів на управлінські посади не враховують соціально-психологічні фактори, які б змотивували врахування способів мислення, системного впливу i можливостей особистостей і колективів на активну участь в управлінні, що не дозволяє задіяти психологічні чинники в позитивних змінах у суспільстві.

Водночас пропоновані засоби системного мислення й інтелектуальних здібностей людей для застосування архетипічної методології в підвищенні ефективності публічного управління територіальних громад не охоплюють усіх необхідних архетипів систем управління в розбудові демократичного суспільства. Необхідно мати базове аналітичне підгрунтя для пізнання реальних можливостей застосування архетипного підходу в системі публічної влади в умовах трансформаційних процесів. Його можна створити за допомогою аналітико-синтетичної моделі "Універсального епохального циклу” Е. Афоніна, яка дозволяє провести соціально-історичний аналіз розвитку суспільства і цивілізації, заглиблюючись до самих підвалин суспільного існування людини [2].

Висновки і перспективи подальших досліджень. Системне мислення, системне бачення, системне удосконалення i системний розвиток стають ключовими поняттями людського світосприйняття, що спонукає до глибоких досліджень їх трансформації і застосування в різних сферах людської діяльності.

Застосування вже відомих системних архетипів управління на- дає можливості розпізнавати діючі системи публічного управління територій, їх архетипічні й інтелектуальні моделі, що сприятимуть вирішенню сьогоденних багатоманітних завдань демократичного управління і здатності керівників вносити необхідні своєчасні зміни в керовані процеси і впливати на їх соцієтальні здібності. Тому процес опанування системного мислення і формування інтелектуальних моделей повинен бути цілеспрямованим і керованим.

Розвиток суспільного мислення стає потужним джерелом формування інтелекту, як окремої особистості, так і колективів. При цьому збагачується і архетипи людини, що створює умови розвитку системних архетипів, зокрема в державному i муніципальному управлінні.

Необхідним є створення умов для розширення концепції удосконалення організаційно-змістовних і функціональних форм систем управління, які будуть враховувати поведінкові теорії, структурні образи колективного несвідомого, тенденції і динаміку архетипічних шарів реальності, здобутки кібернетики, системність мислення й інтелектуалізацію процесів управління.

Подальшими напрямами дослідження означеної проблеми повинні стати: створення аналітичних моделей аналізу якості систем управління на первісному рівні суспільства - територіальних громад; виявлення існуючих проблем і оцінювання здатності влади до їх вирішення; розробка методології опанування кібернетичними системними архетипами управління i розробка методів їх практичної побудови i 
функціонування; концептуалізація архетипного і системного підходів у підвищенні ефективності публічного управління для їх застосування на практиці; розробка змісту доповнень в освітні програми підготовки майбутніх фахівців з публічного управління в закладах вищої освіти, центрах підготовки та підвищення кваліфікації управлінських кадрів для набуття знань і навичок розвитку системного мислення й інтелекту з використанням комп'ютерних технологій.

\section{СПИСОК ВИКОРИСТАНИХ} ДЖЕРЕЛ

1. Символическое и архетипическое в культуре и социальных отношениях: материалы III междунар. науч.-практ. конф., 5 - 6 марта 2013 г., Прага : Vědecko vydavatelské centrum "Sociosféra - CZ", 2013. $175 \mathrm{c}$.

2. Суший О. В. Українське диво. Український соціум. 2018. № 4(67). С. 162-165.

3. Бельська Т. В. Архетипні концептуальні засади становлення і розвитку глобального громадянського суспільства. Публічне управління: теорія та практика. 2014. № 2(18). С. 14-22.

4. Суший О. В. Психосоціальна культура державного управління: монографія. Київ : Світогляд, 2012. 344 с.

5. Афонін Е. А. Балакірєва О. М. Функціональна і компетентнісна готовність державних службовців України до здійснення публічного адміністрування в умовах демократії: наук.-аналіт. доповідна записка. Київ : 2015. 24 с.

6. Афонін Е. В., Балакірєва О. М. Функціональна i компетентнісна готовність державних службовців
України до здійснення публічного адміністрування в умовах демократіï. Український соціум. 2015. № 1. C. 7-22.

7. Афонін Е. А. Людська ідентичність та особливості їі впливу на політику й державне управління. Концептуальні засади взаємодії політики і управління : навч. посіб. Київ : НАДУ, 2010. С. 265-289.

8. Афонін Е. А. Суший О. В. Закономірності та особливості суспільно-трансформаційних процесів в Україні. Український соціум. 2011. № 4. C. 7-30.

9. Суший Е. В., Афонин Э. А. Архетипика как новое научное направление междисциплинарных исследований проблем государственного управления Государственное управление в XXI веке: традиции и инновации : материалы 9-й междунар. конф., г. Москва, 25-27 мая 2011 г. Москва: Изд-во Моск. ун-та, 2011. Ч. 3. С. 111-122.

10. Афонін Е., Мартинов А. Українське диво: від депресії до соціального оптимізму: монографія. Київ : Києво-Могилянська академія, 2019. $296 \mathrm{c}$.

11. Саймон Геберт А. Адміністративна поведінка: Дослідження процесів прийняття рішень в організаціях, що виконують адміністративні функції; пер. с англ. за заг. ред. Р. Ткачук. Київ: АртЕк, 2001. 392 с.

12. Сенге П. Пятая дисциплина: Искусство и практика самообучающейся организации : пер. с англ. Москва : Олимп - Бизнес, 1999. 408 с.

13. Юнг К. Сознание и бессознательное. Москва : Академический Проект, 2009. 188 c.

14. Енциклопедія кібернетики : у 2 т. / редкол. : В. М. Глушков (відп. ред.), М. М. Амосов, І. П. Артеменко [та ін.]; АН Української РСР. - Київ : Голов. ред. Укр. рад. енцикл., 1973. Т. 2. 570 с. 
15. Фрейдина Е. В. Исследование систем управления : учебно-методический комплекс. Новосибирск : НГУЭУ, 2007. 184 с.

16. Бир Стаффорд. Кибернетика и управление производством. - Москва : Наука, 1965. 391 с.

\section{REFERENCES}

1. Proceedings of the 3 Conference Title (2013): mezhdunarodnaia nauchnopraktycheskaia konferentsyia "Symvolycheskoe y arkhetypycheskoe v kulture y sotsyalnыkh otnoshenyiakh"

- International scientific-practical conference "Symbolic and archetypal in culture and social relations". (175 p.). Praha: Vědecko vydavatelské centrum "Sociosféra - CZ" [in Czech Republic].

2. Sushyi, O. V. (2018). Ukrainske dyvo [The Ukrainian miracle]. Ukrainskyi sotsium. - Ukrainian society, 4(67), 162-165 [in Ukrainian].

3. Bielska, T. V. (2014). Arkhetypni kontseptualni zasady stanovlennia i rozvytku hlobalnoho hromadianskoho suspilstva [Archetypal conceptual foundations for the emergence and development of global civil society]. Publichne upravlinnia: teoriia ta praktyka. - Public administration: theory and practice, 2(18), 14-22 [in Ukrainian].

4. Sushyi, O. V. (2012). Psykhosotsialna kultura derzhavnoho upravlinnia [Psychosocial culture of public administration]. - Kyiv: Svitohliad [in Ukrainian].

5. Afonin, E. A. \& Balakirieva, O. M. (2015). Funktsionalna i kompetentnisna hotovnist derzhavnykh sluzhbovtsiv Ukrainy do zdiisnennia publichnoho administruvannia $\mathrm{v}$ umovakh demokratii [Functional and Competent Willingness of Ukrainian Civil Servants to Perform Public Administration in Democracy]. nauk.-analit. dopovidna zapyska. Kyiv: DU "In- stytut ekonomiky ta prohnozuvannia Natsionalnoi akademii nauk Ukrainy" [in Ukrainian].

6. Afonin, E. V. \& Balakirieva, O. M. (2015). Funktsionalna i kompetentnisna hotovnist derzhavnykh sluzhbovtsiv Ukrainy do zdiisnennia publichnoho administruvannia $\mathrm{v}$ umovakh demokratii [Functional and Competent Willingness of Ukrainian Civil Servants to Perform Public Administration in Democracy]. Ukrainskyi sotsium - Ukrainian society, 1, 7-22 [in Ukrainian].

7. Afonin, E. A. (2010). Liudska identychnist ta osoblyvosti yii vplyvu na polityku y derzhavne upravlinnia [Human Identity and its Impacts on Politics and Public Administration] Kontseptualni zasady vzaiemodii polityky i upravlinnia - Conceptual framework for policy-management synergies, (pp. 265-289). Kyiv : NADU [in Ukrainian].

8. Afonin, E. A., Sushyi, O. V. \& Usachenko, L. M. (2011). Zakonomirnosti ta osoblyvosti suspilno-transformatsiinykh protsesiv $\mathrm{v}$ Ukraini [Patterns and features of social and transformation processes in Ukraine]. Ukrainskyi sotsium. - Ukrainian society, 4(67), 7-30 [in Ukrainian].

9. Sushyi, E. V. \& Afonin, E. A. (2011). Arkhetypyka kak novoe nauchnoe napravlenye mezhdystsyplynarnыkh yssledovanyi problem hosudarstvennoho upravlenyia [Archetypal as a new scientific field of interdisciplinary research of public administration problems]: Proceedings of the 9rd International: International Conference "Hosudarstvennoe upravlenye v KhKhI veke: tradytsyy y ynnovatsyy" - materials of the 9th international conference "Public Administration in the 21st Century: Traditions and Innovations". (Vols. 2). (pp. 111-122). Moscow: Yzd-vo Mosk. un-ta [in Russian]. 
10. Afonin, E. \& Martynov, A. (2019). Ukrainske dyvo: vid depresii do sotsialnoho optymizmu [The Ukrainian miracle: from depression to social optimism]. Kyiv: Kyievo-Mohylianska akademiia [in Ukrainian].

11. Hebert, Saimon A. (2001). Administratyvna povedinka: Doslidzhennia protsesiv pryiniattia rishen $\mathrm{v}$ orhanizatsiiakh, shcho vykonuiut administratyvni funktsii [Administrative Behavior: Investigating Decision Making Processes in Organizations Performing Administrative Functions]. (Trans). Kyiv : ArtEk [in Ukrainian].

12. Senhe P. (1999). Piataia dystsyplyna: Ysskustvo y praktyka samoobuchaiushcheisia orhanyzatsyy [Fifth discipline: The art and practice of self- study organization]. (Trans). Moscow: Olymp - Byznes [in Russian].

13. Iunh, K. (2009). Soznanye y bessoznatelnoe [Consciousness and the unconscious]. - Moscow: Akademycheskyi Proekt [in Russian].

14. Hlushkov, V.M. (Ed.). (1973). Entsyklopediia kibernetyky [Encyclopedia of Cybernetics]. (Vols. 1-2). Kyiv: Holovna redaktsiia Ukrainskoi radianskoi entsyklopedii [in Ukrainian].

15. Freidyna, E.V. (2007). Yssledovanye system upravlenyia [Management systems research]. Novosybyrsk: NHUЭU [in Russian].

16. Byr, S. (1965). Kybernetyka y upravlenye proyzvodstvom [Cybernetics and production management]. Moscow: Nauka [in Russian]. 